Vol. 12 (2003): 107-115.

\title{
Effect of liming on yield and quality of peppermint and Sachalin mint in fine sand soil of Northern Finland
}

\author{
Abbas Aflatuni \\ MTT Agrifood Research Finland, North Ostrobothnia Research Station, FIN-92400 Ruukki, Finland, \\ e-mail:abbas.aflatuni@mtt.fi \\ Jouko Uusitalo, Sari Ek \\ University of Oulu, Laboratory of Mass Spectrometry, Department of Chemistry, FIN-90014 Oulu, Finland \\ Anja Hohtola \\ University of Oulu, Department of Biology, Botany, FIN-90014 Oulu, Finland
}

\begin{abstract}
Soil acidity commonly limits plant production in the fine sand soil of Northern Finland, which often has a low $\mathrm{pH}(5.5-6.5)$ and contains low levels of $\mathrm{Ca}$ and $\mathrm{Mg}$. The effect of five liming (10\% $\mathrm{Mg}$ and $19 \% \mathrm{Ca}$ ) levels, $0,4,8,12$, and 16 tons $\mathrm{ha}^{-1}$, on the herb and essential oil yield and menthol and menthone content of two mint species (peppermint, Mentha x piperita, a variety of Black Mitcham and Sachalin mint, Mentha arvensis var. sacchalinensis) cultivated in fine sand soil in Northern Finland $\left(64^{\circ} 40^{\prime} \mathrm{N}\right.$ and $\left.25^{\circ} 05^{\prime} \mathrm{E}\right)$ was studied during $1998-2000$. Liming clearly increased the pH levels and the $\mathrm{Ca}$ and $\mathrm{Mg}$ content of the soil. The dry matter content, essential oil quantity, and the menthol or menthone content in mints were not affected by liming. In comparison with no liming however, liming at a rate of $4 \mathrm{tha}^{-1}$ doubled the herb yield. The highest yield was achieved in Sachalin mint by liming at 4 or $8 \mathrm{t} \mathrm{ha}^{-1}$ in the second and third year (soil pH 6-6.5) (Ca 725-871 $\mathrm{mg} \mathrm{l}^{-1}$ and $\mathrm{Mg} 122$ $219 \mathrm{mg} \mathrm{l}^{-1}$ ), and in peppermint by liming at 4,8 or $16 \mathrm{t} \mathrm{ha}^{-1}$ (soil pH 6-6.6) (Ca 725-1272 $\mathrm{mg} \mathrm{l}^{-1}$ and Mg 122-245 $\mathrm{mg}^{-1}$ ). Therefore, we conclude that a higher peppermint and Sachalin mint yield is achieved by increasing soil $\mathrm{pH}$ to values above 6.0 in the fine sand soil of Northern Finland.
\end{abstract}

Key words: Lamiaceae, lime, Mentha arvensis var. sacchalinensis, Mentha x piperita, menthone, menthol, $\mathrm{pH}$, roots, stolons

\section{Introduction}

Over the past few years, different herb species have been a subject of continuous interest to consumers, growers, and researchers in Finland.
Peppermint (Mentha piperita L.), a member of the Lamiaceae family, is a rhizomatous aromatic plant widely cultivated in many countries, such as the USA, India, China, the former USSR, Italy, France and Hungary. Its essential oil is considered industrially important (Lawrence 1985) 


\section{Aflatuni, A. et al. Effect of liming on two mint species}

as it is used in pharmaceuticals, confectionery, alcoholic beverages, chewing gum, dental creams and cosmetics, and its leaves are used in food flavoring, tea and folk medicine (Gupta 1991). Each year, Finland imports about $8 \mathrm{t}$ of dry mint leaves, 10-20 t of peppermint essential oil, and $10 \mathrm{t}$ of pure menthol (National Board of Customs 1984-1996). Many reports on the benefits of long days of sunlight for mint cultivation (Burbott and Loomis 1967, Clark and Menary 1980) make increasing Finnish production an attractive proposition.

Soil pH profoundly affects the growth and nutrient uptake by crops. Shukla et al. (1997, 1998) observed that different levels of soil $\mathrm{pH}$ influenced the fresh and dry weight and the essential oil yield of peppermint. It has been found that high levels of $\mathrm{Mg}$ in nutrient solution increase the leaf essential oil content of Mentha arvensis without significantly altering the quality of the essential oil (Zimma and Piekos 1988, Maia et al. 2001). The leaves of peppermint are rich in $\mathrm{K}$ and $\mathrm{Mg}$ (Berbec and Kolodziej 1996).

One of the factors limiting plant production in Finland is soil acidity; the average $\mathrm{pH}$ value of agricultural soils in 1981-1987 was 5.8 (Kähäri et al. 1987). The $\mathrm{pH}$ range in the fine sand soil of Northern Finland is 5.5-6.5, and liming is commonly needed. The acidic sandy soils of Northern Finland are also poor in $\mathrm{Ca}$ and $\mathrm{Mg}$. It is to be expected that liming the soil is necessary in order to profitably cultivate mints in acidic soils.

At present, the cultivation of mint is very limited in Finland. In order to offer farmers in North- ern Finland a new source of income, a project was started to examine the optimal conditions for the cultivation of mint. Because of favorable light conditions (long days) and cool nights, high quality essential oil yield can be expected (Franz 1984). In this particular study, the impact of liming (including the manipulation of soil $\mathrm{pH}$ and the contents of $\mathrm{Ca}$ and $\mathrm{Mg}$ ) on the yield and quality of Mentha x piperita and Mentha arvensis var. sacchalinensis species was investigated during a three-year field experiment.

\section{Material and methods}

\section{Plant material and the field experiment}

The experiment was established in 1998 in Ruukki (Northern Finland) at the North Ostrobothnia Research Station of MTT Agrifood Research Finland, $64^{\circ} 40^{\prime} \mathrm{N}$ and $25^{\circ} 05^{\prime} \mathrm{E}$. It was set up in a randomized split-plot design of four blocks (Gomez and Gomez 1984), where the main plots were laid out in each block according to a randomized complete block design. There were two main plots (mint species) in each block: 1) Mentha x piperita "Peppermint" (a variety of Black Mitcham, originally from Egypt) and 2) Mentha arvensis var. sacchalinensis (originally from Hungary).

Table 1 shows the experimental field treatment dates in 1998-2000. The amount of N, P, and $\mathrm{K}$ applied annually were 40,28 , and $56 \mathrm{~kg}$ $\mathrm{ha}^{-1}$, respectively. The lime was spread manual-

Table 1. The treatment dates of the field experiments in 1998-2000.

\begin{tabular}{lccc}
\hline Treatment & 1998 & 1999 & 2000 \\
\hline Soil sampling & 28 May and 15 Sep & & 11 May \\
Fertilizer application & 7 Jun & 7 Jun & 22 May \\
Liming & 7 Jun & - & - \\
Planting & 9 Jun & - & - \\
Harvesting & 27 Aug & 17 Aug & 15 Aug \\
Root and stolon & & & 16 Aug \\
development observation & & & \\
\hline
\end{tabular}


Vol. 12 (2003): 107-115.

ly before fertilization and mixed immediately after being spread with an S-spike. The subplots received $0,4,8,12$, or $16 \mathrm{t} \mathrm{ha}^{-1}$ of lime. The lime was provided by Saxo Mineral Oy in Tornio (Northern Finland). The lime contained more than $10 \% \mathrm{Mg}$ and more than $19 \% \mathrm{Ca}$. The fast acting neutralizing capability of liming was $35 \%$ of the material, according to the Finnish pH Stat Method. Determination of the neutralizing value was performed by the Finnish Plant Production Inspection Center (unpublished, as described by Erstad et al. 2000).

The plants were micropropagated. Nodal cuttings were cultured on Murashige and Skoog's (1962) medium for shoot regeneration and on Lloyd \& McCown's woody plant medium (1980) for rooting. The rooted plants were planted after fertilization and liming in the experimental field in spring 1998. The plot size was $1.5 \times 5 \mathrm{~m}$ (= $7.5 \mathrm{~m}^{2}$ ); the distance between the rows was $75 \mathrm{~cm}$ and the distance between the plants in the rows was $20 \mathrm{~cm}$.

\section{Analyses}

Samples for soil analyses were taken in May 1998 before liming and fertilization and in September 1998 and May 2000 after liming and fertilization (Tables 1 and 2). Five subsamples were taken from each subplot replication (liming level) and mixed in order to obtain one sample of approximately 0.51 from each liming level. The sampling depth was $0-20 \mathrm{~cm}$. In this experiment, an analysis of statistical error was not possible because only one sample per liming level was taken.

The samples were analyzed by Soil Analysis Service Ltd. The soil texture and organic matter content were estimated by finger assessment. The soil texture was that of fine sand containing 6$12 \%$ of organic matter. To analyze soil nutrients, $25 \mathrm{ml}$ of soil was extracted with $250 \mathrm{ml}$ of acidic ammonium acetate $(\mathrm{pH} 4.65)$ (Vuorinen and Mäkitie 1955) and a plasma emission spectrometer was used for the determinations. A spectrophotometer was used for the determination of $\mathrm{P}$. After standing 12 hours, the soil $\mathrm{pH}$ and electrical conductivity (EC) were determined in soilwater suspension (1:2.5). A specific electrode was used to measure both the $\mathrm{pH}$ and $\mathrm{EC}$ in this suspension.The results of the analyses before liming and fertilizing were: soil texture, fine sand with $6-12 \%$ of organic matter content and electrical conductivity, $0.8 \mathrm{mS} \mathrm{cm}^{-1}, \mathrm{pH} 5.8$, and $\mathrm{Ca}$ 677, P 21, K 214 and $\mathrm{Mg} 41.6 \mathrm{mg} \mathrm{l}^{-1}$ of soil.

The fresh yield was determined after harvest: dried $\left(\right.$ at $\left.+40^{\circ} \mathrm{C}\right)$ random samples $(2 \times 200 \mathrm{~g})$ were used to assess dry matter content and to estimate the concentration of essential oil. To

Table 2. The results of soil analyses after liming and fertilizing in 1998 and 2000.

\begin{tabular}{|c|c|c|c|c|c|}
\hline \multirow[t]{2}{*}{ Analysis } & \multicolumn{5}{|c|}{ Liming level $\mathrm{tha}^{-1}$} \\
\hline & 0 & 4 & 8 & 12 & 16 \\
\hline \multicolumn{6}{|c|}{ September 1998} \\
\hline $\mathrm{pH}$ & 5.5 & 6.0 & 6.1 & 6.4 & 6.5 \\
\hline $\mathrm{Ca} \mathrm{mg}^{-1}$ & 569 & 725 & 836 & 979 & 1270 \\
\hline $\mathrm{P} \mathrm{mg} \mathrm{l}^{-1}$ & 26 & 25 & 25 & 25 & 26 \\
\hline $\mathrm{K} \mathrm{mg} \mathrm{l}^{-1}$ & 141 & 119 & 128 & 127 & 138 \\
\hline 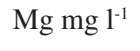 & 48 & 122 & 168 & 202 & 223 \\
\hline \multicolumn{6}{|l|}{ May 2000} \\
\hline $\mathrm{pH}$ & 5.5 & 6.0 & 6.5 & 6.6 & 6.6 \\
\hline $\mathrm{Ca} \mathrm{mg} \mathrm{l}^{-1}$ & 527 & 754 & 871 & 892 & 1272 \\
\hline $\mathrm{P} \mathrm{mg} \mathrm{l}^{-1}$ & 23 & 25 & 24 & 22 & 24 \\
\hline $\mathrm{K} \operatorname{mg} 1^{-1}$ & 197 & 199 & 203 & 194 & 192 \\
\hline $\operatorname{Mg~mg~}^{-1}$ & 72 & 176 & 219 & 214 & 245 \\
\hline
\end{tabular}


Aflatuni, A. et al. Effect of liming on two mint species

isolate the essential oil, mint leaves (50 g) were dried at $+30^{\circ} \mathrm{C}$ and then mixed with $700 \mathrm{ml}$ of water which was subsequently hydrodistilled for $2 \mathrm{~h}$ at $120^{\circ} \mathrm{C}$ at atmospheric pressure. The essential oil content was then measured (Pohjamo 1994).

The constituents of the essential oil were analyzed using GC and identified by GC/Ms. Sample preparation: Leaf samples, which were selected to represent leaves of all ages, were collected at random from randomly selected plants. Gas chromatography was performed with a Perkin Elmer Autosystem XL gas chromatograph using helium as the carrier gas at a constant pressure mode ( $37 \mathrm{psig}$ ).

The sample components were identified by mass spectra matching with a Wiley/NBS Registry Mass Spectra Data Base. The identifications were verified by comparing the retention time and mass spectrum with, when possible, a reference compound.

\section{Root and stolon observation}

When finishing the experiment, root and stolon samples were taken from each plot in the year 2000 in order to observe their development. The root density, the number of stolons, as well as the weight of roots and stolons, were measured. The density of roots and the number of stolons were evaluated on a scale of $1-4$, in which 1 was remarkably few, 2 few, 3 optimum and 4 many. The observation dates are shown in Table 1.

\section{Weather conditions during the experiment}

The monthly average temperature in the summer 1998 was lower than normal in North Ostrobothnia and in the summer 1999, it was close to normal; in the year 2000, May and July were higher than normal (Table 3). The precipitation in the summers of 1998 and 2000 were higher than normal and in 1999, it was close to average.
Table 3. The monthly mean summer temperatures $\left({ }^{\circ} \mathrm{C}\right)$ in 1998-2000 and long-term average in Ruukki. Data provided by the Finnish Meteorological Institute.

\begin{tabular}{lrrrr}
\hline & \multicolumn{4}{c}{ Year } \\
Month & 1998 & 1999 & 2000 & $1961-90$ \\
\hline May & 6.3 & 5.4 & 8.9 & 7.7 \\
June & 12.7 & 15.5 & 13.1 & 13.2 \\
July & 15.4 & 15.8 & 16.3 & 15.4 \\
August & 12.4 & 11.7 & 13.1 & 13.1 \\
\hline
\end{tabular}

\section{Statistical methods}

The randomization method led to the split-plot experimental design. Hence, the response variables were analyzed using the traditional ANOVA for split-plot design (Gomez and Gomez 1984).

Measurements of fresh yield and essential oil content were repeated several times for each plot. The repeated measurements tended to correlate, which was taken into account in the model used. The covariance structure of the repeated measurements was chosen by comparing potential structures using Akaike and Schwarz's Bayesian information criterion (Wolfinger 1996). The model, and the assumptions used, was illustrated by Gumperetz and Brow (1993).

The assumptions in both models were checked graphically by box-plot in order to test the normality of errors; plots of residuals were used to test the constancy of error variance (Neter et al. 1996). The parameters of the models were estimated by the restricted maximum likelihood (REML) estimation method using the SAS system for Windows, release 8.1.

\section{Results and discussion}

\section{Impact of liming on soil}

Liming clearly increased the $\mathrm{Ca}$ and $\mathrm{Mg}$ content of the soil (Table 2). In Finland, there are no rec- 
Vol. 12 (2003): 107-115.

ommended soil nutrient levels for herbs. According to Soil Analysis Service Ltd (1997), a Ca content of 1400-2000 $\mathrm{mg} \mathrm{l}^{-1}$ and an $\mathrm{Mg}$ content of 120-200 $\mathrm{mg} \mathrm{l}^{-1}$, which is the targeted level, are satisfactory in fine sand soil used for growing outdoor vegetables. The $\mathrm{Ca}$ and $\mathrm{Mg}$ levels in the experimental field were initially lower than the ranges recommended by Soil Analysis Service (see Table 2) but the satisfactory values were achieved after liming.

In 1998, the soil $\mathrm{pH}$ in plots after liming with $4,8,12$, and $16 \mathrm{t} \mathrm{ha}^{-1}$ were respectively $0.5,0.6$, 0.9 , and 1.0 units higher than in plots with no liming: the $\mathrm{pH}$ range in liming levels in 19982000 was 6-6.6. Although liming was performed only in 1998, the soil pH levels in plots limed with higher amounts than $4 \mathrm{t} \mathrm{ha}^{-1}$ seemed to be higher in 2000 than they were in 1998, probably due to the slow dissolution of lime. Similarly, according to Kemppainen et al. (1993), after liming with 8 or $12 \mathrm{t} \mathrm{ha}^{-1}$ in the first year of trials, the $\mathrm{pH}$ level increased during the 7 years of experiment in fine sand while at $4 \mathrm{t} \mathrm{ha}^{-1} \mathrm{pH}$ level, the $\mathrm{pH}$ rose only in the first year and remained the same during the 7 years. The recommended $\mathrm{pH}$ value for all soils is 6.5-7 (Soil Analysis Service 1997).

\section{Yield, oil content, and menthol and menthone content}

Liming had the most pronounced effect on fresh yield (Table 4). In 1999, the fresh yield of Sachalin mint was significantly, and for peppermint almost significantly, higher with liming in comparison with no liming (Table 4).

In 2000, the yields were much lower than in the two previous years, which was due to weeds, bad overwintering, and plant age. Galambosi (1995) also found a decrease in yields of biological mint in trials performed in South Mikkeli, Finland. Moreover, according to Hornok (1992), a peppermint plantation should be maintained for two, or rarely, for three years and it should not be cultivated in the same field for four years due to increases of weeds, insects, and diseases. In our experiment, however, all plants were healthy and no signs of disease were observed.

In this experiment, the effect of liming on the fresh yield of Sachalin mint was almost significant. The yield of Sachalin mint was higher with liming at a level of 4 or $8 \mathrm{t} \mathrm{ha}^{-1}$ (Soil $\mathrm{pH}$ 6-6.5) in comparison with no liming (soil pH 5.5). The highest yield of peppermint was also achieved

Table 4. Fresh yield of the Sachalin mint and peppermint $\left(\mathrm{kg} \mathrm{ha}^{-1}\right)$ in 1998-2000 at different liming levels.

\begin{tabular}{|c|c|c|c|c|c|c|}
\hline \multirow[t]{2}{*}{ Species } & \multicolumn{5}{|c|}{ Liming level t ha-1 } & \multirow[t]{2}{*}{ P-value* } \\
\hline & 0 & 4 & 8 & 12 & 16 & \\
\hline \multicolumn{7}{|l|}{ Year 1998} \\
\hline Sachalin mint & 7867 & 12267 & 9600 & 13334 & 12400 & 0.06 \\
\hline Peppermint & 16267 & 16667 & 16933 & 18266 & 17200 & 0.88 \\
\hline Mean & 12000 & 14400 & 13333 & 15733 & 14800 & 0.11 \\
\hline \multicolumn{7}{|l|}{ Year 1999} \\
\hline Sachalin mint & 10933 & 24800 & 23733 & 23333 & 27866 & $<0.005$ \\
\hline Peppermint & 9200 & 16333 & 15867 & 14800 & 17600 & 0.05 \\
\hline Mean & 10133 & 20400 & 19733 & 19067 & 22666 & $<0.001$ \\
\hline \multicolumn{7}{|l|}{ Year 2000} \\
\hline Sachalin mint & 2800 & 7200 & 6600 & 2533 & 2133 & 0.05 \\
\hline Peppermit & 1333 & 2120 & 2016 & 1466 & 1867 & 0.06 \\
\hline Mean & 2060 & 4550 & 4250 & 1985 & 1888 & 0.08 \\
\hline
\end{tabular}

$\mathrm{P}$-value* $=\mathrm{P}$-value between five liming level differences 


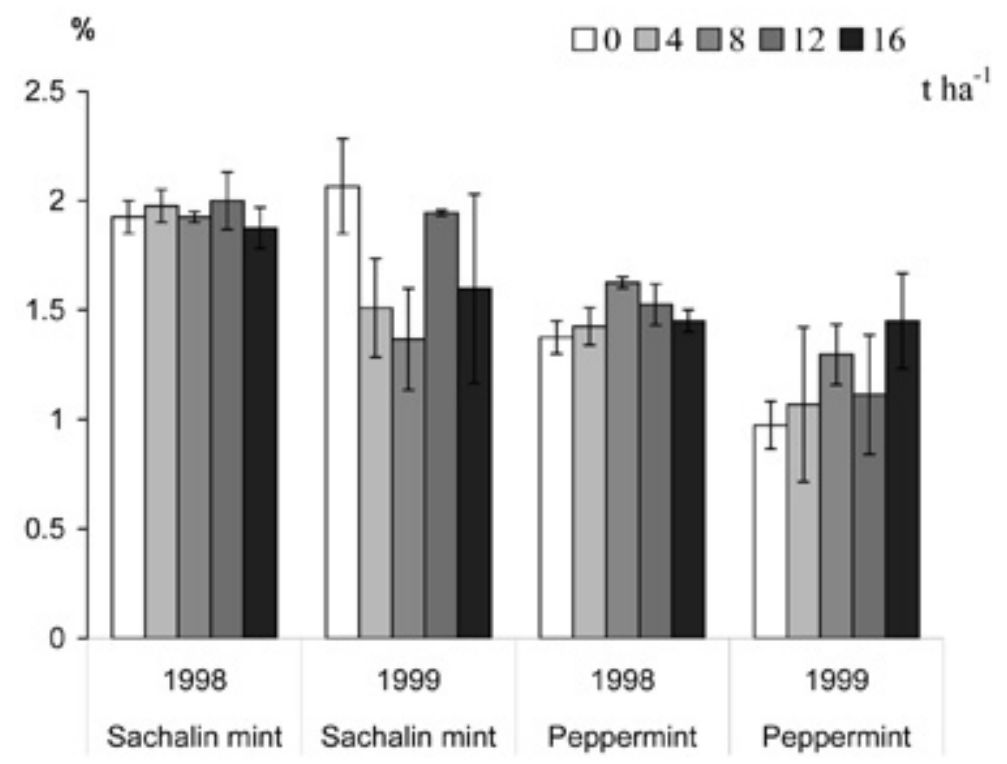

Fig. 1. Essential oil content (\%) in dry leaves of Sachalin mint and peppermint in 1998-1999 at different liming levels.

with the liming level of 4 or 8 in comparison with no liming, but only in the second and third years (1998 and 2000) after application. The average yield for three years shows that liming with $4 \mathrm{tha}^{-1}$ gave almost the same yield as with 8 and 12 t ha $^{-1}$. Matusiewicz (1972) studied peppermint of the Mitcham variety for three years in five combinations of soil $\mathrm{pH}$, ranging from 4.7 to 6.9. He concluded that the plants developed best and gave the highest crop of plant material at soil $\mathrm{pH}$ ranging from 5.6 to 6.2 . In addition to low $\mathrm{pH}$, the reason for low yield could also be $\mathrm{Ca}$ and $\mathrm{Mg}$ deficiency, which limited the yield in treatments when liming was not applied.

The dry matter content for Sachalin mint in 1998,1999 , and 2000 was $17-18 \%, 18-19 \%$, and $17-19 \%$, and for peppermint it was $13-14 \%, 19-$ $20 \%$, and $19-21 \%$, respectively. Liming did not have any effect on the percentage of dry matter. Differences in dry matter were seen between different species $(\mathrm{P}<0.0001)$ and between different years $(\mathrm{P}<0.0001)$.

Liming did not affect the essential oil content of Sachalin mint $(\mathrm{P}=0.38$ in 1998 and $\mathrm{P}=$ 0.16 in 1999 , ) and peppermint $(\mathrm{P}=0.16$ in 1989 and $\mathrm{P}=0.71$ in 1999 ,) (Fig. 1). The slightly (0.02) higher essential oil yield was achieved in 1998 by liming in Sachalin mint (Fig. 2). In 1999, although the essential oil yield was higher with liming than without it, the differences in both mints were not significant because of the wide random variation. Wide random variation in essential oil yield is due to factors in the field other than genetic differences, as the plant material used in this experiment was micropropagated. The menthol and menthone content of Sachalin mint and peppermint were not influenced by liming (Table 5).

\section{Development of rootage}

Both the deficiency and excess of minerals has a negative effect on root growth. The effect of liming on the weight and density of roots in the soil was not significant, but Sachalin mint roots were longer $(\mathrm{P}<0.001)$ in limed plots at the $\mathrm{pH}$ 6-6.5, in comparison with unlimed plots $(\mathrm{pH}$ 5.5). In peppermint, the difference in root length was not statistically significant (Table 5). 
Vol. 12 (2003): 107-115.

Fig. 2. Essential oil yield $\left(\mathrm{kg} \mathrm{ha}^{-1}\right)$ of Sachalin mint and peppermint in 1998-1999 at different liming levels.

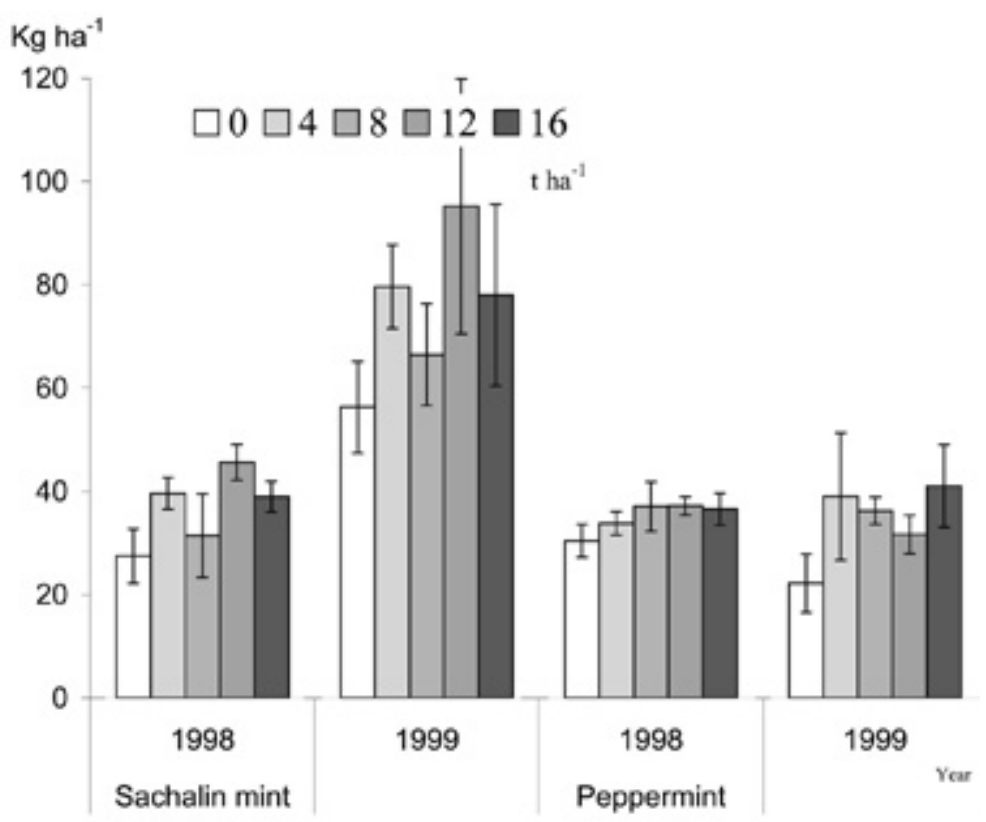

Table 5. The growth of mint rootage and contents of menthol and menthone (\%) of total peak area at different liming levels.

\begin{tabular}{|c|c|c|c|c|c|c|c|}
\hline & \multicolumn{5}{|c|}{ Liming levels $\mathrm{t} \mathrm{ha}^{-1}$} & \multicolumn{2}{|c|}{ Significance } \\
\hline & 0 & 4 & 8 & 12 & 16 & SEM & $\mathrm{P} 1$ \\
\hline \multicolumn{8}{|l|}{ Sachalin mint } \\
\hline Root density per plant, $1-4$ scale* & 1.8 & 2.0 & 2.3 & 1.8 & 2.0 & 0.28 & 0.25 \\
\hline Number of stolons per plant, $1-4$ scale* & $* \quad 1.5$ & 2.3 & 2.0 & 1.8 & 2.0 & 0.29 & 0.14 \\
\hline Root and stolons, g per plant & 124 & 162 & 277 & 135 & 235 & 79.0 & 0.38 \\
\hline Root length, cm per plant & 11.9 & 15.8 & 18.3 & 16.5 & 22.8 & 2.44 & $<0.001$ \\
\hline Menthol \% & 82.5 & 81.8 & 80.8 & 82.5 & 82.9 & 1.53 & 0.88 \\
\hline Menthone \% & 10.5 & 8.90 & 9.20 & 8.40 & 7.60 & 1.09 & 0.54 \\
\hline \multicolumn{8}{|l|}{ Peppermint } \\
\hline Root density per plant, $1-4$ scale* & 3.8 & 3.5 & 3.5 & 4.0 & 3.0 & 0.28 & 0.41 \\
\hline Number of stolons per plant, $1-4$ scale* & $* \quad 3.5$ & 3.0 & 3.8 & 4.0 & 3.0 & 0.29 & 0.85 \\
\hline Root and stolons, g per plant & 656 & 642 & 599 & 736 & 441 & 79.0 & 0.56 \\
\hline Root length, cm per plant & 19.5 & 22.3 & 21.5 & 22.8 & 20.3 & 2.44 & 0.40 \\
\hline Menthol \% & 53.5 & 46.3 & 51.3 & 48.9 & 52.0 & 3.94 & 0.72 \\
\hline Menthone & 20.5 & 24.8 & 22.1 & 22.2 & 22.2 & 4.72 & 0.98 \\
\hline
\end{tabular}

SEM = standard error of mean

$\mathrm{P} 1=\mathrm{P}$ value between 0 and other lime level

Scale $* 1=$ remarkably few, $2=$ few, $3=$ optimum and $4=$ abundant 


\section{Summary and conclusions}

By applying $4 \mathrm{t} \mathrm{ha}^{-1}$ of lime, the $\mathrm{pH}$ rose from 5.5 to 6 in fine sand soil with $6-12 \%$ organic matter content. Liming almost doubled the fresh herb yield of both Sachalin mint and peppermint. The essential oil yield was higher in Sachalin mint in the first year. Liming had no effect on the essential oil content and proportion of menthol and menthone; neither did it have any effect on the development of peppermint rootage. However, liming at the level of 4 or $8 \mathrm{t} \mathrm{ha}^{-1}$
(pH 6-6.1) did have a positive effect on the length of roots in Sachalin mint.

In conclusion, if the soil $\mathrm{pH}$ value is lower than 6 or the $\mathrm{Mg}$ and $\mathrm{Ca}$ are low, liming at the level of 4-8 tha-1 in the sandy soil of Northern Finland is recommended in order to achieve a higher fresh yield and a higher essential oil yield. Liming with $12 \mathrm{t} \mathrm{ha}^{-1}$ produces almost the same yield as with $4 \mathrm{t} \mathrm{ha}^{-1}$ during the first three years after liming. Liming has no effect on the essential oil content, the proportion of menthol and menthone, or the percentage of dry matter. The roots of Sachalin mint are longer with liming.

\section{References}

Berbec, S. \& Kolodziej, B. 1996. Macro- and microelement content in raw materials of some medicinal plants depending on the period of harvest. Annales Universitatis Mariae Curie Sklodowska 51: 55-61.

Burbott, A.J. \& Loomis W.D. 1967. Effects of light and temperature on the monoterpenes of peppermint. Plant Physiology 42: 20-28

Clark, R.J. \& Menary, R.C. 1980. Environmental effects on peppermint (Mentha piperita L.). I. Effect of daylength, photon flux density, night temperature and day temperature on the yield and composition of peppermint oil. II. Effects of temperature on photosynthesis, photorespiration and dark respiration in peppermint with reference to oil composition. Australian Journal of Plant Physiology 7: 685-697.

Erstad, K.J., Konovalov, Y.N., Putro, J., Rex, M. \& Luukkonen, E. 2000. Reactivity of silicate liming materials from Northern Europe assessed by soil incubation and two $\mathrm{pH}$ stat methods. Agricultural and Food Science in Finland 9: 333-348.

Franz, C. 1984. Influence of the growing site on the quality of Mentha piperita L. oil used for pharmaceutical, cosmetic and flavoring. International Society for Horticultural Science 144: 145-150.

Galambosi, B. 1995. The organic cultivation of spices and medicinal herbs. Mauste- ja rohdosyrttien luonnonmukainen viljely. Helsinki, Painatuskeskus, 234 p. ISBN 951-1530-2.

Gomez, K.A. \& Gomez, A.A. 1984. Statistical procedures for agricultural research. 2nd edition. John Wiley \& Sons, New York. 627 p.

Gumperetz, M.L. \& Brow, C. 1993. Repeated measures in randomized block and split-plot experiments. $\mathrm{Ca}$ nadian Journal of Forest Research 23: 625-639.

Gupta, R. 1991. Agrotechnology of medicinal plants. In: Wijesekera, R.O.B. (ed.). The medicinal plant industry. CRC Press. p. 43-57.
Hornok, L. 1992. Cultivation and processing of medicinal plants. Budapest: Akademia Kiado. 338 p.

Kähäri, J., Mäntylahti, V. \& Rannikko, M. 1987. Soil fertility of Finnish cultivated soils 1981-1985. Soil Analysis Service. $105 \mathrm{p}$.

Kemppainen, E., Jaakkola, A. \& Elonen P. 1993. Peltomaiden kalkitustarve ja kalkituksen vaikutus viljan ja nurmen satoon. (Summary: Effect of liming on yield of cereals and grass.) Maatalouden tutkimuskeskus, Tiedote 15/93. $44 \mathrm{p}$.

Lawrence, B.M. 1985. A review of the world production of essential oils (1984). Perfumer and Flavorist 10: 76.

Lloyd, G. \& McCown, B. 1980. Commercially-feasible micropropagation of mountain laurel, Kalmia latifolia, by use of shoot-tip culture. Combined proceedings of the International Plant Propagators Society 3: 421427.

Maia, N.B., Bovi, O.A., Marques, M.O.M., Granja, N., Carmello, Q.A.C., Granja, N. \& Maloupa, E. 2001. Essential oil production and quality of Mentha arvensis L. grown in nutrient solutions. Acta Horticulturae 548: 181-187.

Matusiewicz, E. 1972. The reaction of Mentha x piperita to soil pH. Prace Komisji Nauk Roliniczch i Komisji Nauk Lesnych PTPN 33: 211-220.

Murashige, T. \& Skoog, F. 1962. A revised medium for rapid growth and bioassays with tobacco tissue culture. Physiologia Plantarum 15: 473-497.

National Board of Customs 1984-1996. Foreign trade. Finnish official statistics. Helsinki 1984-1996.

Neter, J., Kutner, M., Nachtsheim, C. \& Wasserman, W. 1996. Applied linear statistical models. 4th edition. Irwin, Chicago. $1310 \mathrm{p}$.

Pohjamo, M. 1994. The record of aromatic substances from spices. Diploma Thesis. University of Oulu, Bioprocess Engineering laboratory. $70 \mathrm{p}$. 
Vol. 12 (2003): 107-115.

Shukla, P.K., Haseeb, A. \& Srivastava, N.K. 1997. The relation between soil $\mathrm{pH}$ and the reproduction/damage potential of Pratylenchus thornei on growth and oil yield of Mentha spicata. Nematologia Mediterranea 25: 25-28.

Shukla, P.K., Haseeb, A. \& Srivastava, N.K. 1998. Influence of $\mathrm{pH}$ on reproduction and damage potential of Pratylenchus thornei on Mentha $x$ piperita. Fundamental and Applied Nematology 21: 103-105.

Soil Analysis Service 1997. Viljavuustutkimuksen tulkinta avomaan puutarhaviljelyssä. (The interpretation of soil productivity of outdoor horticulture). Soil Analysis Service Ltd, Mikkeli. 21 p. (in Finnish).
Stevens, R.J. \& Laughlin, R.J. 1996. Effects of lime and nitrogen fertilizer on two sward types over a 10-year period. Journal of Agricultural Science 127: 451-461.

Vuorinen, J. \& Mäkitie, O. 1955. The method of soil testing in use in Finland. Agrogeological Publication 63: $1-44$.

Wolfinger, R. 1996. Heterogeneous variance-covariance structures for repeated measures. Journal of Agricultural, Biological, and Environmental Statistics 2: 205-230.

Zimma, D. \& Piekos, R. 1988. Extraction of eight essential elements from the leaves of peppermint, Mentha piperita (L.) Huds. Herba Hungarica 27: 65-75.

\title{
SELOSTUS
}

\section{Kalkituksen vaikutus piparmintun ja Sachalinin mintun satoon Pohjois-Suomessa}

\author{
Abbas Aflatuni, Jouko Uusitalo, Sari Ek ja Anja Hohtola \\ MTT (Maa- ja elintarviketalouden tutkimuskeskus) ja Oulun yliopisto
}

Maan happamuus rajoittaa yleisesti kasvien tuotantoa Pohjois-Suomen hienohietamailla, joiden $\mathrm{pH}$ vaihtelee 5,5-6,5 ja kalsium- ja magnesiumtaso ovat yleensä alhaisia. Kalkituksen vaikutusta kahden mintun (piparminttu, Mentha x piperita, lajike Black Mitcham ja Sachalinin minttu, Mentha arvensis var. sacchalinensis) satoon sekä haihtuvan öljyn määrään, mentoli- ja mentonipitoisuteen tutkittiin Pohjois-Suomessa vuosina 1998-2000. Kalkkia (10\% Mg ja $19 \% \mathrm{Ca}$ ) levitettiin joko 0, 4, 8, 12 tai 16 t/ha. Maalaji oli hienoa hietaa.

Kalkitus nosti selvästi maan pH:ta sekä kalsiumja magnesiumtasoa. Kalkitus ei vaikuttanut sadon kui- va-ainepitoisuuteen, öljyn määrään eikä mentolin tai mentonin pitoisuuteen. Neljä t/ha kalkkia saaneilta aloilta tuoresato oli kaksi kertaa suurempi kuin aloilta, joita ei oltu kalkittu. Sachalinin mintun sato oli suurin, kun sitä kalkittiin 4-8 t/ha toisena ja kolmantena vuonna (maan pH 6-6,5, Ca 725-871 mg/l and Mg 122-219 mg/l). Piparmintun sato oli suurin, kun sitä kalkittiin 4, 8 tai 16 t/ha (maan $\mathrm{pH}$ 6-6,6, Ca $725-1272$ mg/l ja Mg 122-245 mg/l). Näin ollen Pohjois-Suomen hienolla hietamaalla voidaan saada hyvä piparmintun ja Sachalinin mintun sato, kun maan $\mathrm{pH}$ on yli 6 . 
